\title{
AMERICAN LABOUR AND CONSENSUS CAPITALISM, 1935-1990
}


The Contemporary United States

Series Editors: CHRISTOPHER BROOKEMAN AND WILLIAM ISSEL

PUBLISHED TITLES

Michael Bradshaw

REGIONS AND REGIONALISM IN THE UNITED STATES

Christopher Brookeman

AMERICAN CULTURE AND SOCIETY SINCE THE 1930s

Kenneth Fox

METROPOLITAN AMERICA: URBAN LIFE AND URBAN

POLIGY IN THE UNITED STATES, 1940-1980

Rochelle Gatlin

AMERICAN WOMEN SINCE 1945

William Issel

SOGIAL GHANGE IN THE UNITED STATES 1945-1983

Manning Marable

RACE, REFORM AND REBELLION: THE SECOND

REGONSTRUGTION IN BLACK AMERICA 1945-1982

Leonard Quart and Albert Auster

AMERICAN FILM AND SOCIETY SINCE 1945

Patrick Renshaw

AMERICAN LABOUR AND CONSENSUS CAPITALISM, 1935-1990

FORTHCOMING TITLES

Michael Dunne

AMERICAN FOREIGN RELATIONS SINGE WORLD WAR II

Sam Rosenberg

AMERICAN ECONOMIC DEVELOPMENT SINCE 1945 


\section{AMERICAN LABOUR AND CONSENSUS CAPITALISM, 1935-1990}

Patrick Renshaw

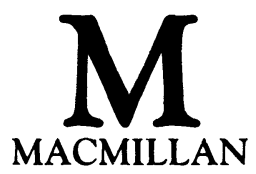


All rights reserved. No reproduction, copy or transmission of this publication may be made without written permission.

No paragraph of this publication may be reproduced, copied or transmitted save with written permission or in accordance with the provisions of the Copyright, Designs and Patents Act

1988 or under the terms of any licence permitting limited copying issued by the Copyright Licensing Agency, 33-4 Alfred Place, London WC1E 7DP.

Any person who does any unauthorized act in relation to this publication may be liable to criminal prosecution and civil claims for damages.

First published 1991

Published by

MACMILLAN EDUCATION LTD

Houndmills, Basingstoke, Hampshire RG21 2XS

and London

Companies and representatives

throughout the world

Typeset by Footnote Graphics,

Warminster, Wiltshire

British Library Cataloguing in Publication Data

Renshaw, Patrick

American labour and consensus capitalism, 1935-1990 - (The

Contemporary United States).

1. United States, 1901-

I. Title II. Series

973.9

ISBN 978-0-333-42866-5

DOI 10.1007/978-1-349-21605-5

\section{Series Standing Order (The Contemporary United States)}

If you would like to receive future titles in this series as they are published, you can make use of our standing order facility. To place a standing order please contact your bookseller or, in case of difficulty, write to us at the address below with your name and address and the name of the series. Please state with which title you wish to begin your standing order. (If you live outside the United Kingdom we may not have the rights for your area, in which case we will forward your order to the publisher concerned.)

Customer Services Department, Macmillan Distribution Ltd, Houndmills, Basingstoke, Hampshire, RG21 2XS, England. 
To the memory of Philip Maynard Williams (1920-84), my tutor, mentor and close friend for thirty years 
'You remember the workingman? You used to write an awful lot about the workingman. He's turning into something called organized labor. You're not going to like that one little bit when you find out it means that your workingman expects something as his right and not your gift. Charlie, when your precious underprivileged really get together - oh, boy, that's going to add up to something bigger than your privilege, and then I don't know what you'll do.'

Jedadiah Leland to Charles Foster Kane in the movie Citizen Kane 


\section{Contents}

Editors'Preface $\quad$ ix

Acknowledgements $\quad \mathrm{x}$

Author's Note on Spelling xiv

Abbreviations $\quad \mathrm{xV}$

Introduction $\quad$ xvi

1 LABOUR AND THE GREAT DEPRESSION 1

2 NEW DEAL RENAISSANCE 20

3 THE GRUCIBLE OF WAR 42

4 RECONVERSION AND REAGTION

5 PURGING THE COMMUNISTS 100

6 THE EMERGENCE OF CORPORATE CONSENSUS 125

7 THE COLLAPSE OF THE KEYNESIAN ECONOMY 152

8 CONGLUSION 184

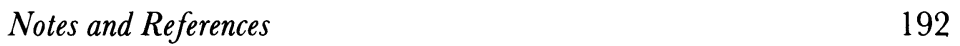

Bibliography 205

Index 223 


\section{Editors' Preface}

Mention the United States and few people respond with feelings of neutrality. Discussions about the role of the United States in the contemporary world typically evoke a sense of admiration or a shudder of dislike. Pundits and politicians alike make sweeping references to attributes of modern society deemed 'characteristically American'. Yet qualifications are in order, especially regarding the distinctiveness of American society and the uniqueness of American culture. True, American society has been shaped by the size of the country, the migratory habits of the people and the federal system of government. Certainly, American culture cannot be understood apart from its multi-cultural character, its irreverence for tradition and its worship of technological imagery. It is equally true, however, that life in the United States has been profoundly shaped by the dynamics of American capitalism and by the penetration of capitalist market imperatives into all aspects of daily life.

The series is designed to take advantage of the growth of specialised research about post-war America in order to foster understanding of the period as a whole as well as to offer a critical assessment of the leading developments of the post-war years. Coming to terms with the United States since 1945 requires a willingness to accept complexity and ambiguity, for the history encompasses conflict as well as consensus, hope as well as despair, progress as well as stagnation. Each book in the series offers an interpretation designed to spark discussion rather than a definite account intended to close debate. The series as a whole is meant to offer students, teachers and the general public fresh perspectives and new insights about the contemporary United States.

CHRistopher BROOKEMAN WiLLIAM ISSEL. 


\section{Acknowledgements}

This book has been written at intervals between research and teaching in other fields. Work started in the United States in the academic year 1981-82 on a research fellowship awarded by the American Council of Learned Societies. The ACLS has sponsored generations of scholars from all parts of the world, in every aspect of American Studies. In expressing my personal thanks, I salute the ACLS for the part it has played in deepening foreign understanding of America.

The Department of History at Sheffield University granted study leave so that I could spend a semester at the State University of New York in Binghamton. The History Department there provided congenial surroundings for study, and I benefited from contact with Professor Melvyn Dubofsky, Professor Charles Freedman, Leslie ('Pepi') Levene and others at Binghamton who showed much kindness, and sympathy when family bereavement cut short my stay.

Sheffield University granted further terms of study leave in 1985 and 1989 which enabled me to continue and complete research in both Britain and the United States, while the Foreign Travel and Research Funds helped with transatlantic fares, subsistence and typing costs. Small grants from the British Academy and the cultural Affairs Office of the American Embassy in London also reduced those outof-pocket expenses which academics, unlike businessmen, are expected to pay themselves while working for their employer. The New York State Industrial and Labor Relations Library at Cornell University, with its vast holdings and helpful staff, the incomparable Franklin D. Roosevelt Library at Hyde Park, New York, and the Hagley Collection at Eleutherian Mills, Wilmington, Delaware, all deepened my understanding of the subject I sought to master, and made long hours of desk consideration a pleasure. 
Finally I must record a special word of warmest thanks to Philip Mason and Warner Pflug at the Walter P. Reuther Library of Labor and Urban Affairs at Wayne State University, Detroit, Michigan. Their award of a Kaiser Travel Grant in 1989 enabled me to spend a profitable month in the ideal surroundings of a unique archive collection, redolent of the history of the UAW and the CIO.

Sheffield University Inter-Library Loan Service, the British Library, the Bodleian and Nuffield College Libraries, Oxford, and the libraries of Cardiff and Hull universities were all helpful in enabling me to read other material not readily available.

While working and travelling in North America I was shown hospitality by people too numerous to mention, but I must name Lucinda and Jeremy Jackson, Nancy and Francis Calhoun, Pat and Irving Nyman, two of my oldest friends, and Carol and Stan Oakleaf, two of my newest, who also enabled me to fulfil a boyhood ambition to meet 'a gal in Kalamazoo'. Many friends and colleagues at Syracuse University, New York, always made me welcome when my itinerary took me to upstate New York.

In the 22 years I have worked at Sheffield, its history department has become one of the best in Britain, and it is a pleasure to thank colleagues for the stimulus they have provided over the years to research and writing. In particular, I wish to name Richard Carwardine (a distant kinsman of one of this book's major protagonists John L. Lewis), Richard Thurlow, Stephen Salter and John Stevenson, and two of my graduate students, Michael Woodiwiss and Steven Swann, for help and encouragement. My brother Geoffrey Renshaw corrected errors in my economic statistics. My greatest intellectual debt, recorded in the book's dedication, is to Philip Williams, Fellow of Nuffield College until his death on 16 November 1984, a teacher who inspired students from all over the world. That this book has taken so long to write is indicative of the impact the so-called 'Thatcher revolution' has had on British universities, forcing academics to devote increasing time and energy to administration, cost cutting, fund raising, promotional work and union agitation, rather than to the teaching and research their contracts of employment require. Future labour historians will find the story of industrial relations at British universities in the 1980s instructive.

All historians learn from, borrow from, dissent from and use the work of contemporaries and predecessors, but I wish to make a 
special acknowledgement here to those whose work has proved most helpful. Melvyn Dubofsky and Warren Van Tine collaborated to write John L. Lewis: a Biography, the finest life of any American labour leader, a study which grows more impressive the more one learns about its subject and his times. Professor Dubofsky's revision of Foster R. Dulles, Labor in America: a History was also invaluable in providing narrative links to the analysis attempted in the following pages. Mel's relentless eye will spot the joins and, I hope, recall Oscar Wilde's remark about imitation being the sincerest form of flattery.

Professor Van Tine's The Making of a Labor Bureaucrat, though set in an earlier period than mine, influenced my own approach. Professor Nelson Lichtenstein, Labor's War at Home: the CIO in World War II was a pathfinding book about the 1940s, while Howell J. Harris, The Right to Manage, which I had the pleasure and good fortune to examine as an Oxford D. Phil dissertation, transformed everyone's picture of the employer's side of industrial relations in the 1940s. Irving Bernstein, Turbulent Years is still the most complete narrative history of labour in the 1930s, while Joel Siedman, American Labor from Defense to Reconversion is an important pioneering study. Harvey Levenstein, Communism, Anti-Communism and the CIO is a dispassionate account of an emotive topic on which chapter 5 of this book relies heavily for its narrative and conclusions.

Finally David Brody, the most gifted interpretative labour historian of his generation, whom I first met when he gave the Anglo-American Lecture at Sheffield in 1989, will see ideas from his essays scattered throughout my text.

My first three chapters include material which first appeared in different form in essays published in the Journal of Contemporary History, vol. 21, no. 1 (January 1986), in Stephen Baskerville and Ralph Willett (eds), Nothing Else to Fear (1985) and Stephen Salter and John Stevenson (eds), The Working Class and Politics in Europe and America (1990). The author and publishers thank the publishers, respectively Sage Publications, Manchester University Press and the Longman Group UK Ltd, for permission to use this material.

Though I still use fountain pen and two-finger typing, this is the age of the touch-typed word processor. Thus Freda Brayshaw worked on early drafts with the same patience and perception she shows when partnering me at bridge, Susan Sharman delivered later 
drafts while Kath Wright typed the whole of the final draft with speed and skill in deciphering an untidy manuscript, and tolerance towards its many changes. Andrew Green and Mareen Smallman helped compile the bibliography, and I must thank Vanessa Couchman, who commissioned this book for the series, her successor Vanessa Graham, and the series' editors, Christopher Brookeman and William Issel for their advice, encouragement and patience. Keith Povey was the best copy-editor I have worked with in a lifetime's writing experience.

None of the people listed above bears responsibility for errors which remain, and all opinions expressed here are my own. Since books on contemporary history cover questions which have a bearing on current political controversies, I should add that I have voted for the British Labour Party in every election since 1957.

My first and last debt is to my wife Mary, who as usual sacrificed her time and much more so that I could spend more of mine working on this book. I owe her everything I most value in life, and her only consolation is that at last I have written about events which took place during our marriage. 


\section{Author's Note on Spelling}

The text follows standard English spelling, as in the word labour. Quotations of course are in standard American usage where the source is American, as in labor, program and cigaret. All American institutions, such as the Defense Department, follow American spelling in the author's text. 


\section{Abbreviations}

AAA Agricultural Adjustment Act

ACTU Association of Catholic Trade Unionists

ACW Amalgamated Clothing Workers

ACTWU Amalgamated Clothing and Textile Workers' Union

ADA

AFL

ALA

Americans for Democratic Action

CGT

American Federation of Labor

CIO

Alliance for Labor Action

Confederation Générale du Travail

CP

Congress of Industrial Organizations

CPA Communist Political Association

FE

Farm Equipment Workers

FO Force Ouvrière

GE

General Electric

GM General Motors

ICFTU International Confederation of Free Trade Unions

ILA International Longshoremen's Association

ILGWU International Ladies' Garment Workers

ILWU International Longshoremen's and Warehousemen's

Union

IWW Industrial Workers of the World

NIRA National Industrial Recovery Act

NLRA National Labor Relations Act

NLRB National Labor Relations Board

NRA National Recovery Administration

NWLB National War Labor Board

SWOC Steel Workers' Organizing Committee

TWOG Textile Workers' Organizing Committee

UAW United Autoworkers

UAW-AFL United Autoworkers faction affiliated to the AFL

UE United Electrical Workers

UFW United Farm Workers

USW United Steelworkers

WFTU World Federation of Trade Unions 


\section{Introduction}

This book's epigraph is taken from the 1940 film script, by Herman J. Mankiewicz and Orson Welles, of Citizen Kane. A song written about the same time by left-wing clothing workers satirised American labour leadership. With capitalism in crisis during the Great Depression, and Socialism alone apparently capable of resisting the threat of world Fascism, the Jewish radicals who wrote the lyric attacked company unions and 'labour fakers' - men like Sidney Hillman, David Dubinsky and Norman Thomas, the Socialist Party candidate for President in 1932. The song, in its entirety, ran as follows:

The cloakmakers' union

Is a no-good union

It's a company union

By the bosses.

The right-wing cloakmakers, And the socialist fakers, Are making by the workers

Double-crosses.

The Hillmans, Dubinskys and the Thomases

Are making by the workers False Promises.

They preach socialism

But they practice fascism

To preserve capitalism

By the bosses.

The epigraph reflects capital's fears about the power organized labour possessed to change the world. The song expresses labour's 
contempt for the way their leaders used that power to betray them. My book tries to explore the ground which lies between these two positions: fear of change and fear of betrayal. American labour did change the world. But far from overthrowing the system, as some hoped it would, unions transformed it so that it worked more efficiently and successfully. What evolved was consensus capitalism, which made America more powerful and helped it dominate an increasingly prosperous Western world.

The rise of organized labour, argued the historian Arthur M. Schlesinger, second only to the two world wars, was what most profoundly shaped the history of the West in the first half of the 20th century. This phenomenon was common to all major industrial nations. But it occurred earlier on the European continent, in Britain and in such English-speaking countries as Australia and New Zealand than it did in the United States. Yet though comparatively late, expansion of American labour unions, once properly underway in the 1930s, was of unprecedented speed. As the celebrated labour intellectual J. B. S. Hardman put it, 'In a matter of only a few years American labor unionism emerged organized, invigorated... The amazingly rapid growth of unionism and its power goes beyond anything ever known. Between 1933 and 1938 union membership tripled from under three to more than nine million.'

Paradoxically, the Great Depression of the 1930s was a major agent in this expansion. At its depth in 1933 the United States, hardest hit of all industrial economies by the Great Depression, appeared to be a helpless giant, its working class devastated and demoralised, its labour unions destroyed. Faced with this moral challenge, the nation elected Franklin D. Roosevelt President and embarked upon a sweeping programme of reform known as the New Deal. During the next 12 years Roosevelt, in peace and war, showed himself to be the greatest democratic leader in American history, and a key figure in world history in the 20th century.

No one, least of all Roosevelt, had any idea what the New Deal would mean in practice. It turned out to be a sweeping programme of reform based upon the idea of 'bold, persistent experimentation'. Such coherence as it had was in the field of political strategy rather than economic theory. Roosevelt knew where the votes were, and the Federal government threw its authority for the first time behind the right of the working class to organize and bargain collectively. So 
labour unions formed part of the Democratic Party's new coalition of liberal, urban reform which set the political agenda for a generation.

But by a process of trial and error, the New Deal also came to embrace the ideas of the British economist J. M. Keynes. The Depression had been caused in general terms because America's capacity to produce goods was tending to outstrip its capacity to consume them. Keynes and some others were struggling to find the answer: use Federal government spending not just to stimulate growth, create more jobs and end unemployment, but also to manage and control the economy. The key to prosperity, on this argument, was raising aggregate demand. So powerful unions, bidding up pay and thus consumption, would play a crucial part. This doctrine of salvation through high wages was naturally seized upon by organized labour, since it rationalised what they wanted to do anyway.

Thus the New Deal greatly strengthened labour's power to organize and bargain collectively, while accelerating acceptance of the high wage economy. This whole process - Federal economic management on Keynesian lines, deficit spending, stronger unions, rising demand - was enhanced by the Second World War. With labour scarce, government and management had to court organized labour to win its support, and make unions joint partners in managing the war economy. By 1945 union membership, at fifteen million, was five times what it had been in 1933. More than twothirds of production workers in manufacturing industry now came under collective bargaining. In transport, coal and metal mining, steel, automobiles, meat packing, rubber and other basic industries unions had organized between 80 and 100 per cent of the workforce. Labour formed a vital part of the Democratic Party coalition. It had firmly entrenched itself into law, industry and economic and political life.

When the war ended in August 1945 America had emerged not just victorious but commanding a position of world dominance, perhaps without precedent in history. In 1933 capitalism had seemed at the point of collapse: Bolshevism or Fascism had seemed like the wave of the future. By 1945 Fascism was vanquished and Bolshevism, though menacing in Eastern Europe, had paid a terrible price for its victory over Nazi Germany. America by contrast, alone among the belligerants, had suffered no domestic 
damage during the war, experienced a wartime boom, enjoyed a monopoly of the atomic bomb, and now dominated the world's economic, financial and political arrangements. She would use this plenitude of power to shape global affairs for a generation. She had won this unique position largely because of her industrial might. This in turn rested on the productive capacity of her industrial working class. In the aftermath of war, Henry Luce, proprietor of Time magazine, spoke of 'the American Century'; Henry Wallace, running as Progressive candidate for President in 1948 and bidding for labour support, saw 'the Century of the Common Man'. In a sense, as the historian Steve Fraser has argued, American labour was caught between these two centuries. Yet what is sometimes called the Keynesian revolution had occurred and labour had been transformed by it. Sometimes in collaboration, sometimes in conflict, government, labour and management hammered out a new foundation for American economic life, which was to shape events for the next thirty years.

The main feature of this relationship was consensus. Each party recognized the right of the other to exist and exercise its authority in its own sphere of influence. The adversarial relationship which had characterized the violent conflicts of the 1930s, and to a lesser extent the war years too, was replaced by management's acceptance of the workers' right to organize unions and of management's right to manage. Increasingly unions were expected to discipline the workforce, while government provided economic conditions which would stimulate greater productivity, profits and pay. In the Red Scare hysteria of the postwar years the unions purged all Communists. Moreover, labour leaders were the most enthusiastic supporters of America's Cold War foreign policy of containment and confrontation with Soviet Russia and Communist China. On this basis American labour enjoyed unparalleled power and influence in the 1950s.

The breakup of this Keynesian consensus was equally important. In answer to a question about the long-run implications of his ideas, Keynes once replied, 'In the long run we are all dead'. It was a revealing response. It meant that Keynes only hoped to plan for a generation, no more. For thirty years Keynesian thinking provided the basis for greater prosperity, more equitably distributed, than at any time in American history. But in the 1960s and 1970s the system began to break down. America no longer dominated the world 
economy but faced increasingly severe competition from Germany and Japan, the nations it had helped defeat in 1945. The inflationary effects of the Vietnam War, the rising costs of oil and other raw materials, de-industrialization and many other social changes, such as discontent and unrest among black Americans and women, all began to undermine the system developed after 1945. When Ronald Reagan took office in January 1981 he promised the people to 'get the government off your backs and out of your pockets'. It marked the end of that New Deal, social reforming, consensus approach to government, which flourished between the 1930s and the 1960s, in which organized labour had prospered.

Although the United States was still, by most yardsticks, the world's leading industrial nation in the 1980s the American working class has rarely received the attention it merits, except from labour historians. Few movies, novels or plays concern themselves with the working class, though the 1950s musical The Pajama Game was about the shop-floor politics of the garment industry, while later films included Blue Collar. Historians focus on ethnicity and race, religion and culture, rather than on social class, and praise British historians like E. P. Thompson for his analysis of the making of the English working class between 1770 and 1840 . In the mass affluence of American society since the 1930s it was almost as if there was a conspiracy to the effect that the working class, like poverty, did not exist in the United States. Yet it was the working class who had done more than anyone to create that affluence, and who were most likely to suffer from poverty when the market place failed them.

Everything manufactured and consumed in America was made, and partly consumed, by them; indeed the growing importance to modern capitalism of working people as consumers is a linking theme of this study. Moreover, the importance of working-class voters in helping create the economic and political reality of modern America is central. In recent years, the fashion among labour historians has been to write less about institutions and labour leaders, more about the daily routines and realities of working-class life. This new labour history has focused less on unions and strikes, more on workplace environment, family life and leisure, women, mothers and children. Some fine work has unearthed important facts and insights which have greatly enhanced understanding of the working-class experience. Yet this book is unashamedly written in the style of the old labour history. It concentrates on unions, strikes, politics, the law 
and the macroeconomic background. While seeking to cover the main events of American labour history for readers new to the subject, it aims at integrating this story into the wider context of the nation's political and economic life since the Great Depression, in the belief that labour history must be judged by its impact on the larger community. 